\title{
Collective action and symbolic capital in the artisanal fisheries: An analysis of the Local Food Systems of Reloncaví Estuary (Los Lagos), Chile
}

\author{
Gonzalo Saavedra Gallo ${ }^{1}$ and Alfredo Macías Vázquez ${ }^{2}$ \\ ${ }^{1}$ Instituto de Estudios Antropológicos, Universidad Austral de Chile, Campus Isla Teja. Valdivia, Chile \\ e-mail: gonzalo.saavedra@uach.cl \\ ${ }^{2}$ Department of Economics, University of Leon, Campus Vegazana, s/n. Leon, Spain \\ e-mail: amacv@unileon.es (corresponding author)
}

Submitted: 15 April 2015. Accepted: 04 November 2015

\begin{abstract}
In a post-industrial economy, it is as important to understand "material" productive processes in the local community as the processes through which global value chains "expropriate" or "co-opt" common immaterial assets. However, the literature on collective action and the management of common goods generally focuses on matters of the control and governance of material resources. The article commences with an analysis of the relations between the production of value, collective action and the rentier nature of contemporary capitalism and its entrepreneurial ideology. Then, we present a detailed analysis of the case of mytilid seed capture in the Reloncaví Estuary (Los Lagos Region, Chile). This case shows us the failure of modernisation policies which are based on converting local producers into modern entrepreneurs. To adopt a successful value strategy, a very different problem must be addressed, namely the difficulties of local communities in managing successfully their own common immaterial values. Faced with the dichotomous logic of neoliberalism, communities must reunite these immaterial values and the associated common material resources, and modulate the friction between them.
\end{abstract}

KEYWORDS: post-industrial economy; knowledge; commons; immaterial value; rent; material resources; governance.

Citation / Cómo citar este artículo: Saavedra Gallo, Gonzalo and Macías Vázquez, Alfredo (2016) "Collective action and symbolic capital in the artisanal fisheries: An analysis of the Local Food Systems of Reloncaví Estuary (Los Lagos), Chile". Culture \& History Digital Journal, 5 (1): e005. doi: http://dx.doi.org/10.3989/chdj.2016.005.

RESUMEN: Acción colectiva y capital simbólico en las pesquerías artesanales: un análisis de los Sistemas Agroalimentarios Locales del Estuario de Reloncaví (Los Lagos), Chile.- En una economía postindustrial, es importante comprender los procesos productivos "materiales" en la comunidad local como procesos a través de los cuales las cadenas globales de valor "expropian" o "cooptan" los activos inmateriales comunes. Sin embargo, la literatura sobre acción colectiva y gestión de los bienes comunes generalmente se focaliza en el control y la gobernanza de los recursos materiales. Este artículo comienza con un análisis de las relaciones entre la producción del valor, la acción colectiva y la naturaleza rentista de capitalismo contemporáneo y su ideología emprendedora. A continuación, presentamos un análisis detallado del caso del cultivo de semillas de mitílidos en el Estuario de Reloncaví (Los Lagos, Chile). El caso nos muestra el fracaso de las políticas de modernización basadas en convertir a los productores locales en empresarios modernos. Para adoptar una estrategia de valorización exitosa, debe abordar un problema muy diferente: las dificultades de las comunidades locales para gestionar exitosamente sus propios valores inmateriales comunes. Enfrentadas con la lógica dicotómica del neoliberalismo, las comunidades deben reunir estos valores inmateriales y los recursos materiales comunes asociados, y modular la fricción entre ellos.

PALABRAS CLAVE: economía posindustrial; conocimiento; bienes comunes; valor inmaterial; renta; recursos materiales; gobernanza.

Copyright: ( 2016 CSIC. This is an open-access article distributed under the terms of the Creative Commons Attribution License (CC BY) Spain 3.0. 


\section{INTRODUCTION}

In recent decades, special attention has been paid to the collective action underlying the reproduction of common goods such as forests, fishery resources or local farm production (Agrawal, 2001). Most of these studies have focused on how collective action is oriented towards the struggle to deal with endogenous and exogenous changes and challenges, and how these affect processes of social exclusion and the overexploitation of common material resources (Ostrom, 1990; Van Laerhoven and Ostrom, 2007). Less attention has been paid to the collective action of local rural communities for the management of their common immaterial assets (Lockie, 2001; Pratt, 2007), which may be understood, according to Harvey (2012), as collective symbolic capital. Currently, global assemblies where conflicts and negotiations can develop over the co-optation, capture and expropriation of such collective symbolic capital are as important as local management of material production. Consequently, it is essential to understand the interconnection between the symbolic capital created around local communities using their localized practices and knowledge, and global value chains.

It is a fact that the increasingly rentier nature of today's capitalist elites habitually leads to appropriation by external actors of the immaterial value produced by these communities, which generally focus their collective attention on material production issues. The valuation of material products increasingly appears in symbolic production processes, this value is then appropriated as a form of income by extra-territorial actors or local elites. Such economic dynamic leads, in the final instance, to the disempowerment of these communities, in the face of both local elites and multinational organisations. We wonder therefore how "local" collectives — as proposed by Escobar (2008) - become inserted in global assemblies, where these appropriation processes are developed, how certain cultural representations occur and how they favour or hinder the exploitation or capture of local immaterial assets by extra-territorial actors or local elites.

The article commences with an analysis of the relations between the production of value, collective action and the rentier nature of contemporary capitalism and its entrepreneurial ideology. We then present a detailed analysis of the case of mytilid seed capture in the Reloncaví Estuary (Los Lagos Region, Chile), followed by some final reflections. A combination of quantitative and qualitative study methodologies were used for the case study conducted in two stages between 2009 and 2012, including ethnographic field work, interviews and focus groups with various local actors. In particular, 28 people linked to mussel cultivation were interviewed and 8 focus groups were arranged in each of the locations where a project to promote seed collection was being implemented (Fondef- Huam AQ08I1018). The sample design was structural rather than probabilistic (Montañés, 2005; Canales, 2006). At the same time, official statis- tics from the Chilean National Fisheries Service (SERNAPESCA) were analysed in order to check quantitative and qualitative data.

\section{COLLECTIVE ACTION, COMMON IMMATERIAL VALUE AND EARNINGS IN A POST-INDUSTRIAL ECONOMY}

The literature on collective action and the management of common goods generally focuses on matters of the control and governance of material resources (Van Laerhoven and Ostrom, 2007). More recently, attention has started to focus on the importance of collective identity in the sustainability of forms of action and long term governance relating to common materials (Araral Jr, 2009; Meinzen-Dick et al., 2004). These works offer dynamic understanding of how communities organise themselves, and how their collective identities are transformed according to the changing realities of common material resources (Mosimane et al., 2012). Nevertheless, an important conclusion is that the different forms of organisation and production of material goods are based on common local immaterial knowledge which is hard to replicate: implicit, informal practical knowledge, artisanal know-how, networks of contacts, information, cooperation, exchange of favours, etc. In parallel, these local entities are increasingly mediated by reflexive consumption and production processes that incorporate exogenous aesthetic values, which are included in local production processes (Alonso González, 2014; Comaroff and Comaroff, 2009). In fact, the collective symbolic capital is a form of social capital that acquires a symbolic character precisely through intersubjective reflection processes, where knowledge or the same material products made by communities may be perceived as different by foreign consumers and other social groups (Siisiäinen, 2003).

According to Rullani (2004), in a post-industrial economy the value of knowledge - and by extension of common immaterial values - derives from the combination of three drivers: the value derived from the interpretative capacity of the consumers of the values and significates incorporated into material production; the number of times that these values and significates are propagated and replicated; and the distribution of the value that they produce among the various actors who help to sustain them. Thus common immaterial assets are the result of the historical crystallisation of an ensemble of practices, social relations, physical qualities and ideas developed by a human group, which can be perceived by other groups, markets or states as "different", and thus object of a process of value attachment. For Harvey (2012), the marks of distinction developed by post-industrial capitalism to maintain the monopolistic extraction of value through earnings on material assets require the participation of immaterial common assets, which attach added value during this process.

These new value production processes mainly associated with such common intangible assets cannot 
be exploited by capitalist elites under traditional forms of value extraction specially developed under Fordism. Therefore, the expropriation of common goods and their added value is intensified by the generation of earnings and the hardening of various forms of immaterial fencing, such as copyrights, patents and trademarks (Marazzi, 2008; Vercellone, 2008). Drawing on these rentier strategies, elites waive generating a higher overall value, implying a better distribution of the benefits of economic activity in the territory (Rullani, 2004). But in return, these elites achieve a simple and direct appropriation of value, because such strategies enable capitalist elites to control market dynamics, strengthening their economic power by generating artificial shortages. In this situation, the struggle of local communities to keep control of the value of their production no longer derives from the organisation of material production so much as the control of common immaterial goods and their modulation by material vectors. Pasquinelli mentions "the profound asymmetry between the cultural domain and the material economy: value is accumulated on the immaterial level but the profits are made on the material one" (2008: 150-151).

So the profit is made through the material vector of production, which depends on intensive internal factors, but the earnings extracted from the product are derived from other symbolic, dynamic, external qualities in the extensive ambit of the immaterial, which escape the control of the producers (the company's reputation, perceptions of quality, growth of local or ecological consumption, etc.). These external factors include consumption patterns and perception of differentiation with respect to other cultures; controlling them is fundamental in order to guarantee that external actors do not establish monopolistic earnings on the common immaterial values of a given community. In the area of food production, various instruments exist to modulate the relationship between material and immaterial values. They seek to establish symbolic relationships between the productive processes of a community and links which may refer to its geography (designations of origin or protected geographical indications, territorial labels, etc.), history (local traditions), products (varieties of grapes, olives, molluscs, etc.), qualities (organoleptic properties, ecological or integrated production, sulphite-free wine, etc.), social activities (gastronomic fairs, cooking competitions, etc.) or forms of know-how (artisanal fishing, farming and agro-industrial techniques, etc.). The effectiveness of these instruments is determined by the relationship between value and power in each particular context. In fact, they do not ensure that communities achieve greater control over the valuation process (Ray, 1998). Additionally, public institutions need to become involved in order for the benefits generated from using collective symbolic capital to be translated into locally appropriate income. As argued from the theoretical approach for localized agrifood systems (Muchnick et al.,
2008; Boucher, 2012; Torres Salcido, 2013), it is necessary to take into account the systemic weaknesses that do not allow added value to be captured locally. The limited sharing of innovation and organizing quality, through to weak inter-institutional cooperation or the non-existent organization of marketing processes, greatly influence the results of these economic dynamics. Some of these weaknesses, in fact, seem to constrain the case study presented here, portraying in part a recurring scenario in the localized systems of food production systems, particularly in Latin American contexts.

\section{THE MUSSEL SEEDS OF THE RELONCAVÍ ESTUARY: THE SYMBOLIC VALUE OF THE PRISTINE, COLLECTIVE ACTION AND ITS TENSIONS}

For at least the last two decades, the Reloncaví Estuary (Cochamó district, Los Lagos Region, Chile) has been one of the principal sources for seed of the Chilean mussel or chorito (Mytilus chilensis). This industry has developed vigorously since 2000 , especially due to growing international demand for the product and the gradual opening up of certain sectors within the Chilean economy to foreign investors (Moulian, 2002; Harvey, 2005). This situation was used particularly by Spanish companies interested in mussel aquaculture, who had experience in freezing and canning their production. In fact, some of these companies were already located in southern Chile, although engaged in canning beach seafood, with comparatively higher costs (Fernández and Giráldez, 2013).

Over the course of a decade, industry growth was remarkable and this was partly due to a deliberate policy of development agencies and investment attraction by Chile (Rivas, 2012). This did not extend to salmon and trout farming, located in the same territory, nevertheless the data are still significant. ${ }^{1}$ The 2013 harvest reached around 250,000 tonnes of mussels, with a total export volume of 65,837 tonnes, equivalent to revenue over US\$ 158million (SERNAPESCA, 2013). Chilean mussel aquaculture had a clear export focus, and would reach a prominent place in international markets in a few years, particularly in Spain, the European Union and the United States, exhibiting a typically transnational character in its territorial deployment. This can be seen in the participation and strategic flow of Spanish capital in certain segments of the mussel value chain. For example, Fernández and Giráldez (2013) point out that in 2011 Spanish companies occupied eight of the top 15 places in the export ranking of processed and canned Chilean mussels, penetrating virtually all segments of the production and distribution process for European markets.

It can be argued that segments in the value chain are heterogeneous and differentiated. In the first links - seed collection and fattening _ producers are capitalized to various extents and associated with various economic and cultural traditions. In general, some seed 
collection takes place in areas managed by artisanal fishermen and farming associations (as in the Reloncaví Estuary), and some fattening is managed by local and national micro-businesses, however, both segments contain large companies (including some Spanish ones). Meanwhile, the related domestic and international processing and distribution markets are generally dominated by large companies (Bagnara and Maltrain, 2008). While there is a strong small business presence in the processes described, including export, the nature of the mussel has favoured the incorporation of communities or artisanal producer associations living near the coast in southern Chile. It can be claimed that mussel aquaculture by collecting naturally-occurring seeds and fattening them, has been a traditional activity for local communities since at least the early twentieth century. Mussels could be found in the baskets that families of fishermen and collectors delivered to the canning plants that had already been installed in the cities of Calbuco and Puerto Montt. ${ }^{2}$

However, community involvement in mussel aquaculture would only be possible during the small business boom since 2000, and especially due to the interventions of public and private local development agencies that noticed the interest of some artisanal fishermen in small-scale aquaculture. Although small businesses installed their own seed collectors or hatcheries, in certain areas historically occupied by coastal communities the potential to collect comparatively better quality seeds was noted (Bagnara and Maltrain, 2008). As mentioned, this applies to the Reloncaví Estuary, hence the explanation of its "entry" into the mussel farming export industry. Needless to say, mussel seed collection is a critical and obviously essential link in the production process. This was evident in recent years when strong international demand meant that some companies encountered serious difficulties in meeting market requirements, under using their technological production capacity (Fernández and Giráldez, 2013).

The settlements along the extended shores of the estuary (Figure 1) are inhabited by farming families who devote a part of their efforts to fishing for demersal species, such as southern hake or cusk eel, or to seafood collection along the shoreline. Although this area formed part of the traditional itineraries of canoe peoples (Martinic, 2005), its recent occupation is due to colonisation processes which occurred in the $19^{\text {th }}$ and $20^{\text {th }}$ centuries, connected basically with the exploitation of alerce forests (Urbina, 2011) and subsequently with settlement by families coming from Chiloé Island and the town of Puerto Montt (Steffen, 1947), who in the long run adopted a seashorefarming cultural model (see photograph 1). During the $20^{\text {th }}$ century this way of life appears to have consolidated equilibrium between land and sea, combining logics of self-sustainment with strategies of forming links with regional and national markets. The principal products traditionally sold were - depending on cycles and harvests potatoes, some green vegetables, sheep, native timber, fish and seafood.

As has frequently occurred in Chile, in particular since the 1990s, there has been progressive intervention

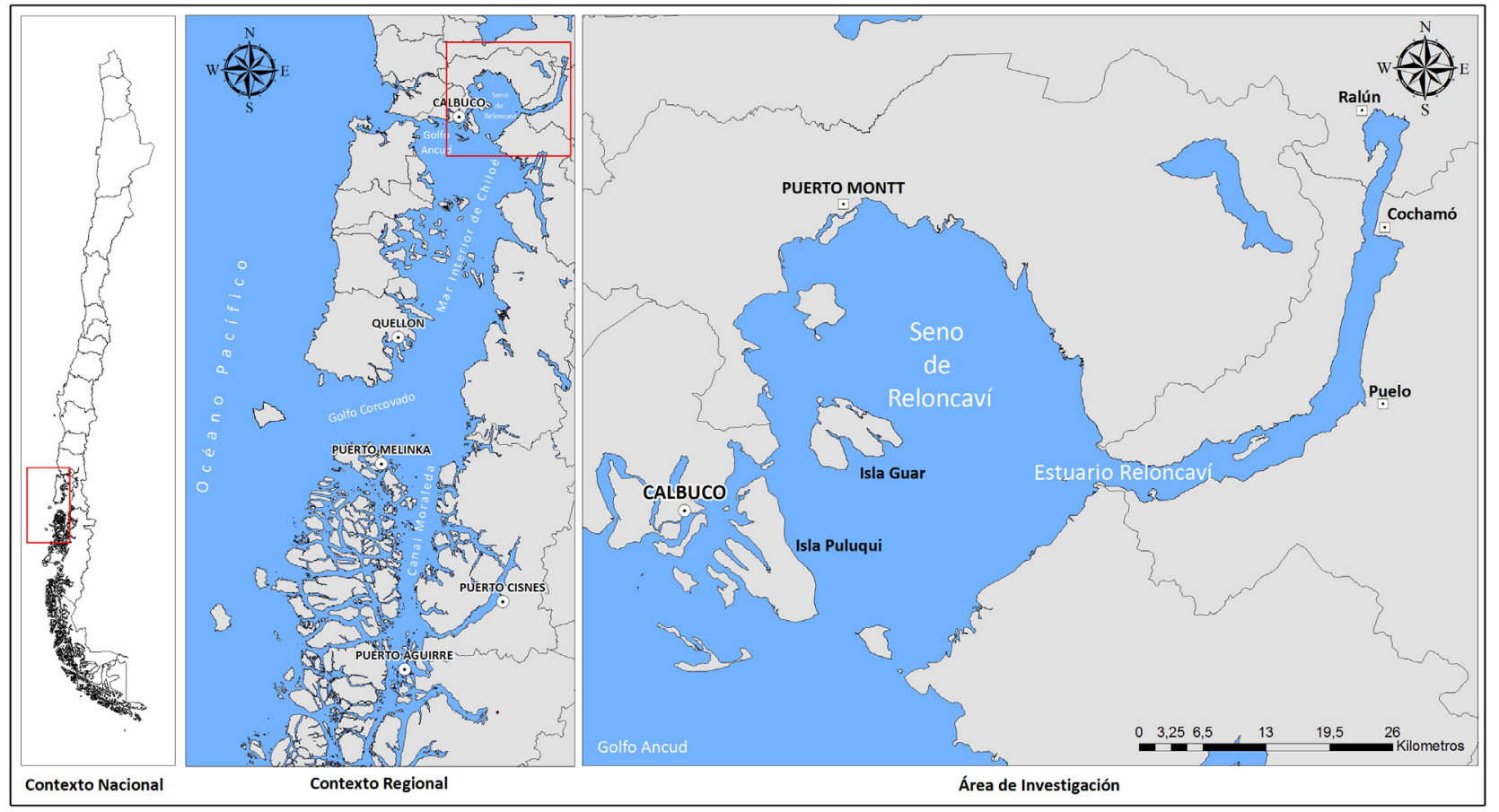

FiguRE 1. Reloncaví Estuary, Los Lagos Region, Chile. Source: Prepared by Zamir Bugueño. 
in rural areas with projects intended to transform, optimise and/or modernise their production systems. The object is to achieve efficient coordination with export markets. The Reloncaví Estuary was no exception, being subject to rapid changes in its use in production based on its incorporation into the value chains of marine aquaculture, first of salmonids and almost simultaneously of mytilids (Figure 2). These interventions display an alignment of private interests with those of the public agency, endorsing an identity dynamic proper to the neoliberal ethos imposed in Chile since the 1970 s, but which became particularly entrenched in the post-dictatorship period (Harvey, 2005; Larraín, 2001).

In this context - once the seeding potential of the Reloncaví Estuary had been established and in conjunction with its reputation as a clean natural space in harmony with traditional seashore cultures (Skewes et al., 2012)the local development experts (part of the bureaucracy of regional public agencies) observed that the shore-dwellers of the estuary should receive specialist assistance. As result, towards the end of the 1990s the first projects were implemented with the aim of increasing the productive and commercial capacity of these economies. There were four factors driving the growth of aquaculture in Chile at that time. First, the passing of the General Law on Fishing and Aquaculture (1991), which legally established and institutionalised species cultivation; second, the interest of public agencies, and especially of some universities, in promoting sustainable production practices in fishing communities; third, the demand of an export market (particularly in Spain) which installed in local expectations what some indigenous leaders have called "the dream of exporting".

The fourth factor is even more contextual, less direct, but with a significant impact. This is the exponential rise of salmon farming in southern Chile. While the history of this activity began in the early twentieth century, it gathered particular momentum in the 1990s when a deliberate strategy to attract domestic and foreign investment began to unfold, in order to configure a growth model and territorial development based on the idea of a cluster (OCDE Chile, 2009; CEPAL, 2010). The southern coastal territory had been called the aquaculture cluster or salmon cluster (Pérez-Alemán, 2005) and this has favoured innovation and growth in the mussel export industry, under a common atmosphere of investment. In fact, the interest in these opportunities was remarkable, to the point that some salmon fishing companies expanded into mussel production (Fernández and Giráldez, 2013).

Meanwhile, after very partial interventions, an applied research project was started between 2009 and 2012; its object was to improve the capacity to capture/ cultivate Mytilus chilensis seeds of eight communities of artisanal fishermen and seashore farmers around the shores of the Reloncaví Estuary. ${ }^{3}$ In particular, the "beneficiaries" of the project were members of the fishermen's syndicates in each of the villages concerned. (Rollizo, Cascajal, Cochamó, Bosquemar, Yates, Sotomó, Sotomó Bajo and Isla Marimeli). All belong to small settlements whose demographics are approximately between 50 and 100 families. For over ten years these fishermen and women had been in contact with agencies and initiatives designed to increase their possibilities for mussel farming. All these interventions, which acted from an objectivising, modernising perspective to achieve structural transformation, sought to take advantage of the "productive vocation" of the territory and the business opportunities offered by the international market at that time.

As previously mentioned, the local conditions in the territory — with good transport links to and from the Region's ports - and the objective quality of the waters meant that longlines were soon installed for seed capture and fattening in the Interior sea of Chiloé. At first, in the 1990s, the investors were companies with Chilean and Spanish capital. Subsequently, after 2000, there was greater interest in local participation among the shore-dwellers and artisanal fishermen. So although it is not precisely an endogenous practice, at least in the Estuary, it may be said - in the case of the fishermen - to be based on a "traditional culture". This then is the second immaterial asset - after the identity of a pristine space - on which musselfarming is based in Chiloé and Reloncaví.

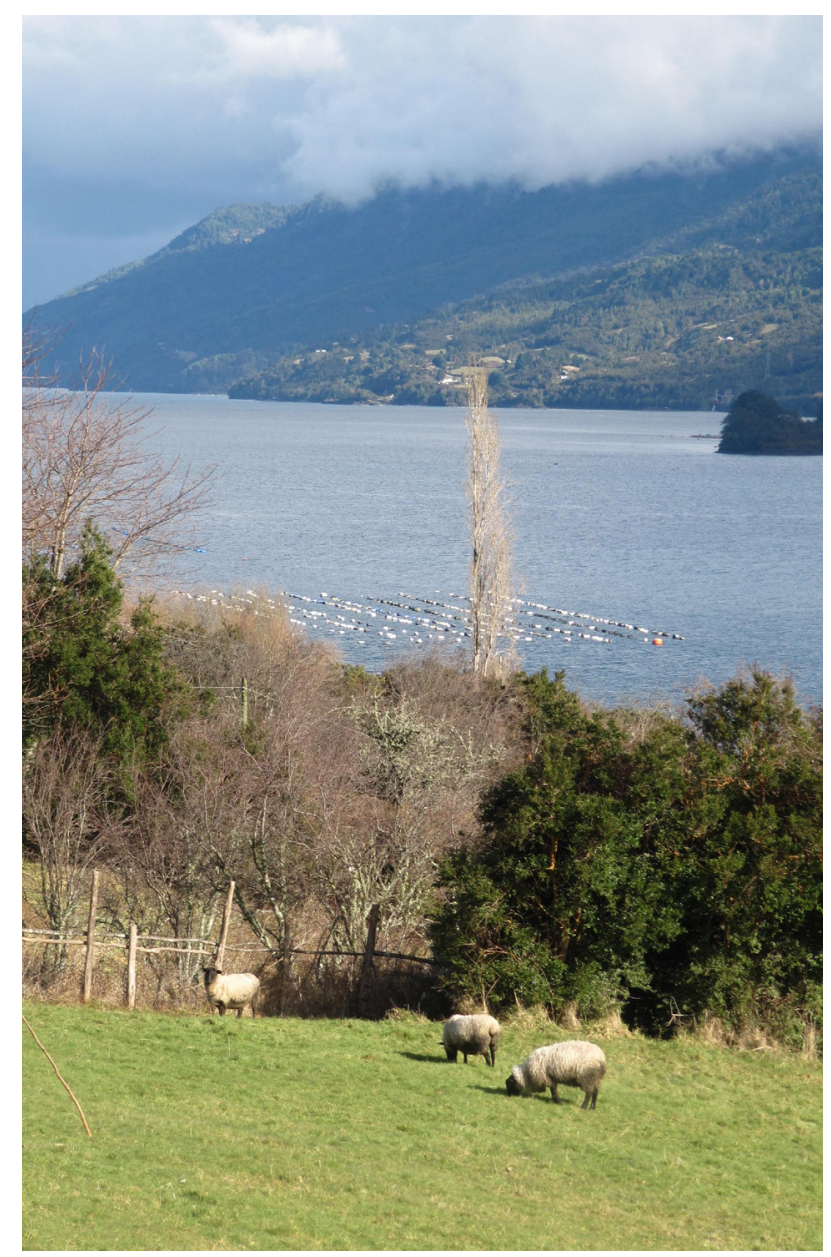

Рното 1. Seashore landscape, Reloncaví estuary. 


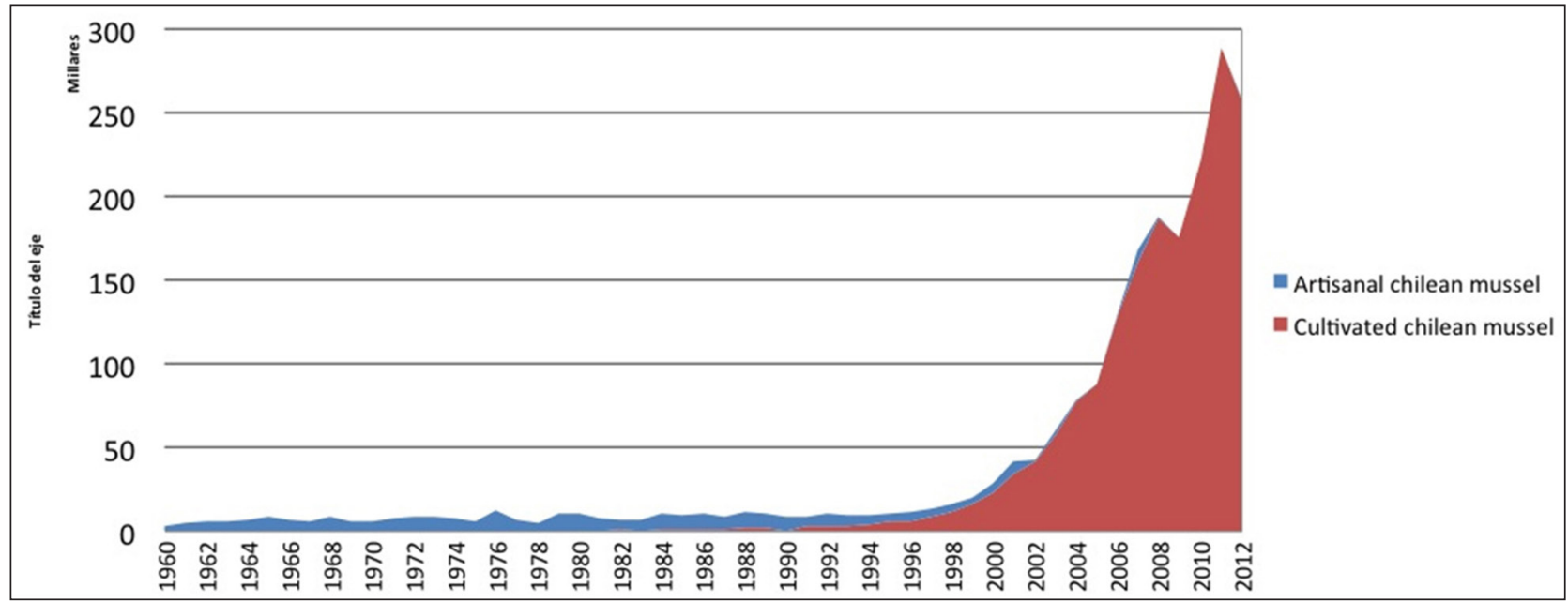

FIgure 2. Catches of Mytilus chilensis (chorito or Chilean mussel), 1960-2012, Los Lagos Region, Chile. Source: Prepared by Claudia Torrijos Kneer from statistical yearbooks of the National Fisheries Service (SERNAPESCA).

\section{TRADITIONAL SEED CAPTURE AND APPROPRIATION BY BUSINESSES OF THE PRODUCT IN THE PRIMARY LINK OF THE VALUE CHAIN}

The artisanal nature of these aquaculture practices, widespread in the Interior sea of Chiloé, is founded on the organisational basis of the process and only indirectly on a "tradition" of artisanal or small-scale aquaculture. It may be noted that this basis fits in with artisanal fishing and coastal peasant farming; we consider that rural, vernacular experience in cultivation cycles goes a long way towards explaining the relative success of Chilean mussel production. It is precisely in this nucleus of the local production system that we will find the traditional component of these practices, at once indirect and ineludible. On the other hand, everything related with specific aspects of production proceeds from technological devices "foreign" to the artisanal system and/or the local coastal territory, which have in fact been "transferred" directly by entrepreneurs or through supported development projects. In the former case, the aim of the companies has been to obtain higher productivity by ensuring a stock of seed from Reloncaví as a "traditional" sector with excellent seed quality. Today, the entire seed production captured by the farming-fishing communities of the Reloncaví Estuary is purchased by centres located in Chiloé and Calbuco. ${ }^{4}$ Figure 3 shows that in the district of Cochamó - where the Estuary and the eight villages are located - there is practically no fattening, only seed production in the artisanal sector. These are data for 2013.

We therefore see that a combination of vectors is involved in the capture, fattening and commercialisation of mussel seeds in the Reloncaví Estuary. On the one hand there is market demand -European in this case, although a marginal increase in domestic consumption has also been recorded - and the incentive from public agencies; and on the other a basis of traditional practices

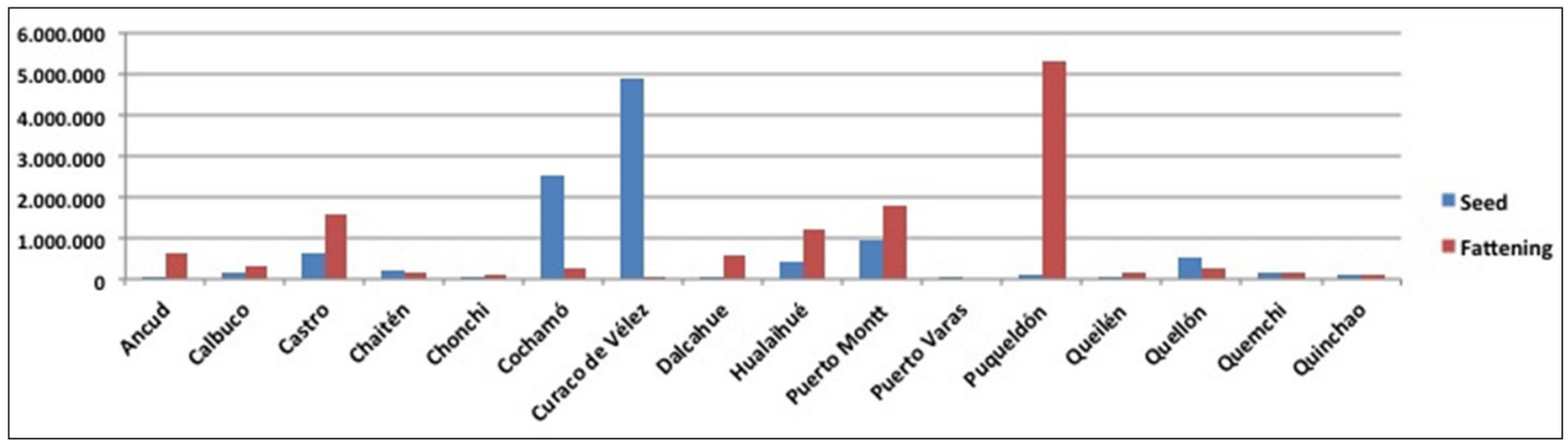

FIGURE 3. Seed capture and fattening of Mytilus chilensis, 2013, in Los Lagos Region, Chile. Source: Prepared by Claudia Torrijos from statistical yearbooks of the National Fisheries Service. 
which allowed for gradual rooting-adaptation of the logic of aquaculture in local economies based on artisanal fishing and farming (Saavedra and Macías, 2012). We also see the conventional coordination typical of multinational neoliberal capitalism: namely the subordination of local production systems to entrepreneurial interests and technology, through the functional inclusion of these local systems in the spaces "colonised" by these companies, in a dynamic that can be understood as characteristic of "global value chains" in Latin American rural areas (Gereffi et al., 2001).

In this context we must stress that this functionality is defined by the added value of the materiality of this seed (quality recognised by the fattening and preparation companies), and also by the confidence that the ecologically pristine waters offer to entrepreneurs, which is an immaterial seal. However, just like the traditional value incorporated into this activity - seashore cultivation - these qualities are not passed down the consumption chain. In other words, the product is not offered for sale with the designation of origin of the seed, or territorial trademarks that mention the place (Reloncaví Estuary), and much less the coastal communities. In fact, profit is extracted from the symbolic values or immaterial assets represented the second link of the chain, by the companies that fatten the seed, process and export the mussels.

\section{THE ROLE OF PUBLIC AGENCIES IN SEED CAPTURE IN THE RELONCAVÍ ESTUARY}

The most common means of seed capture by artisanal fishermen is to lay out longline systems with collectors consisting of old nets. Most of these systems are located in water bodies designated as "temporary occupation permits", an administrative mechanism introduced - as an emergency measure - at the beginning of the 2000 s to respond to the demand for seeds resulting from a scarcity of seed captured in Chiloé and Calbuco (the sites of the main fattening centres). These are in the hands of large and medium sized companies, who use the symbolic value of these territories - typically of seashore farmingto consolidate the profitability of the product in the market. Today, according to unofficial data from the National Fisheries Service, more than $80 \%$ of the seed sold in the region comes from temporary permits (see photographs 2 and 3). A new law is therefore being drafted by the government to create "collectors' parks", and formalise the use of temporary permits by replacing them with aquaculture concessions, ideally under syndicate administration. As stated by one of the partners at the fishermen's syndicate in the town of Cascajal:

We have applied for an aquaculture concession, because over the years we have only had a temporary permit, which requires renewing every year and doing the paperwork, paying for crop lines, paying publicity, and we have had to bear this cost, not the syndicate (Interview, August 2010).
Other mechanisms for using space, apart from aquaculture concessions, are Areas for the Management and Exploitation of Benthic Resources - AMERB - designated exclusively for fishing syndicates by the Department of Fishing and Aquaculture..$^{5}$ The following account was obtained in a focus group in the town of Cochamó, highlighting the combined strategy of using both concessions as an AMERB, within a framework of formalising the activity, where it has resorted to standardised administrative figures derived from the public agency:

The final concession is progressing well and we are asking for two sectors within the area, [so] when the area is released we will have a good choice (panel discussion, March 2011)

Management and administration have combined collective and individual work, as may be seen in the three models described briefly below. They demonstrate the structural importance of the market in the productive system. At this point it is interesting to note that while these are community management models (for seeds and water) whose institutional architecture has been transferred from the State, in practice they have been reformulated according to the organizational dynamics and traditions of the communities and the syndicates themselves.

Until a few decades ago, the Chilean mussel was a secondary product with low demand in the domestic market (Couyoumdjian, 2009). Other products traditionally formed the staple of southern benthic fisheries, particularly cholga (Aulacomya ater) and choro zapato (Choromytilus chorus), and later sea urchin (Loxechinus albus) and abalone (Concholepas concholepas). Mussel production rose quite recently due to the high demand in the Spanish market in the 1990s, and especially since the sinking of the oil tanker "Prestige" in 2002, which affected the mussel banks along the shores of Galicia (Garza et al., 2006). It was in this context that mussel farming began to extend massively in the Interior sea of southern Chile. Reloncaví, as mentioned above, played a central role in the new scenario, given its optimum environmental conditions for seed capture. It has become a primary production base for the process, the first link in the chain. This is the current situation.

The main initiatives for improving production in the Reloncaví Estuary come either from the private business sector or the public sector. One probable explanation is that the production and export of this species was originally controlled by entrepreneurs. At the technological level, all the consumables imply costs which exceed the capacity of artisanal systems, at least at a competitive level (Saavedra and Macías, 2012). Furthermore, the eight syndicates that we visited between 2009 and 2011 had capture lines and buoys put in place by companies or their intermediaries. This is exactly the same system which applies in artisanal fishing. By way of illustration we cite a preliminary observation we made after conducting the focus group in the town of Sotomó: 
The conventional method is for fattening companies or entrepreneurs to "set up" a portion of the lines (collectors, for example), subject to an agreement to "deliver" the entire harvest to the company (through a corporate contract). Prepayments are also used, and in this case there is no possibility of setting or managing prices. Therefore, production and commercial control are completely external (Ethnographic record, May 2010).
The Estuary space presents an unequal relationship, with partial subordination by the companies. On the one hand, the aquaculture facilities of the companies occupy the best sites (they have been granted concessions on large areas) and furthermore they are at the cutting edge of technology. On the other, the lines managed by the syndicates depend on state subsidies or "support" from the companies to ensure their stock and quality. It is true

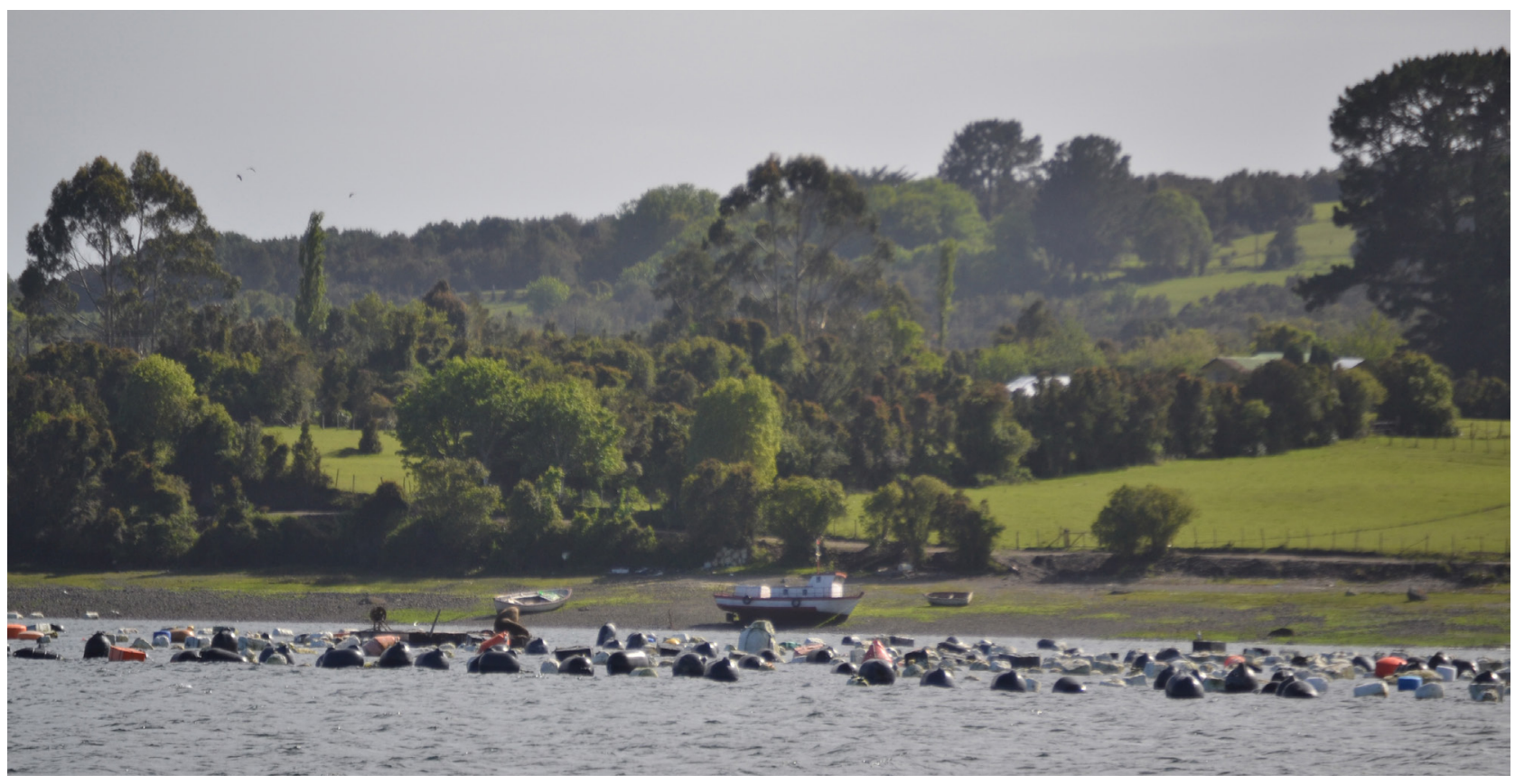

Рното 2. Industrial longlines, Reloncaví.

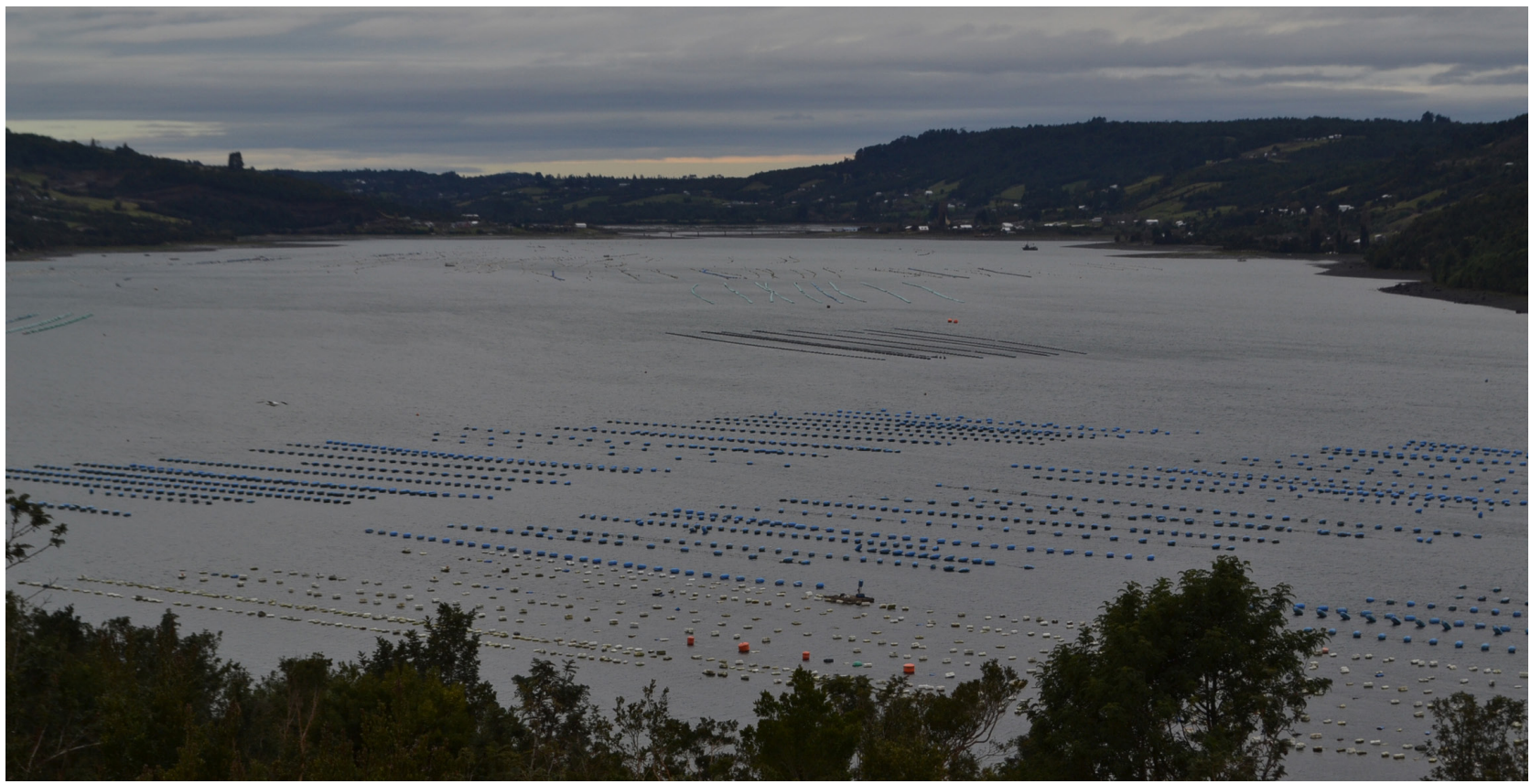

Рното 3. Artisanal longlines, Reloncaví. 
that the implementation of the HUAM Programme (Hacia Una Acuicultura de nivel Mundial - Towards WorldClass Aquaculture), created by the Chilean Government in 2002, has enabled some artisanal producers to become incorporated into a guided quality management process, based on the micro-business model.

We would stress that for artisanal fishermen or local producers the FONDEF-HUAM programme, financed by the Fund for Scientific and Technological Research (FONDECYT), is the most important initiative that has been taken, even though the expected results have only been achieved in specific cases, and the tendency among the syndicates is "not to take advantage" of the knowledge "transferred" in the training offered by experts. Perhaps the best results have been achieved in those syndicates which have drifted towards a microbusiness type of productive-commercial dynamic. However this has not occurred in the syndicates with the most marked community-collectivist basis (see Figures 4 and 5).

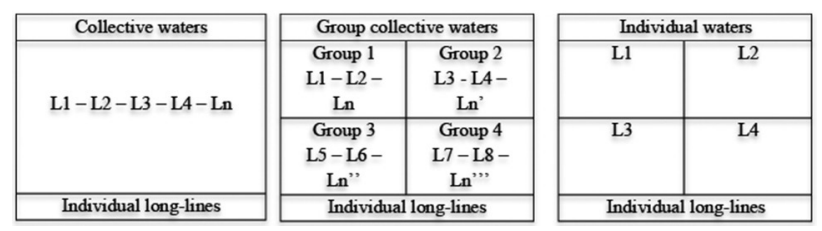

FiguRE 4. Organisational management models in the capture/ production of Mytilus chilensis seeds, Reloncaví Estuary. Source: Authors.
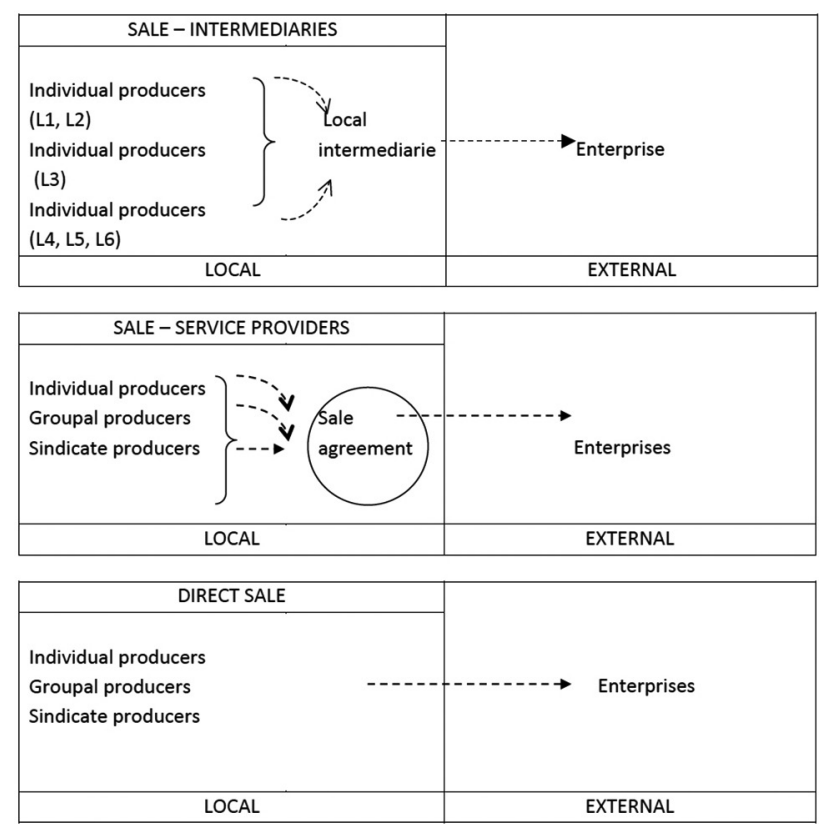

FIGURE 5. Models of sale/commercialisation of Mytilus chilensis seeds through intermediaries in farming-fishing organisations in the Reloncaví Estuary.

Source: Authors.

\section{COLLECTIVE ACTION AND ITS LIMITATIONS IN SEED CAPTURE/PRODUCTION IN THE RELONCAVÍ ESTUARY}

The differential value associated with the production of Mytilus chilensis in the waters of the Reloncaví Estuary depends first and foremost on the quality of the seed and the cleanness of the clusters of mussels. For example, other species of mytilids do not attach themselves to the clusters here - requiring their removal, which has a negative impact on the yield. However, although they form the first link in the value chain, and despite the complexity of the chain as described above, the producer groups which form the syndicates have not been able to obtain income with a territorial differentiation. There are a number of reasons for this; some are structural, related to their subordinate position, while others are territorial, associated with the peripheral location of the Reloncaví Estuary itself in the marine system of southern Chile. ${ }^{6} \mathrm{~A}$ third factor relates to the hydro-biological conditions: because high-quality fattening is not possible in the Estuary, these producers - the first link - tend to become invisible or, in terms of our theoretical discussion, invisible under the logic of territorial subordination in the global assembly of the transnational mussel economy. Of course, interventions carried out in recent years (since 2009) have sought to create transparency in the traceability of the product in order to attach value to quality seed capture in the consumer market (Fondef-Huam Project AQ08I1018, Funchi, 2009). We have not yet seen the desired results.

In practice, obtaining benefits in the form of income for differentiated quality - associated with invisible immaterial values - is restricted by the structure of the commercialisation process. Firstly, as already remarked, the seed producer syndicates — or rather the fishermen who work in seed production - are involved in networks of intermediaries, which dims perception of the important place of the seed producer in the process. Another aspect of this problem is the "laundering" of the product, a strategy based on the use of the existing administrative mechanisms (temporary permits or concessions under decree) to sell seeds which originate in illegal cultivation sites in the Estuary or the neighbouring district of Hualaihué. We see therefore that the primary production link is completely disconnected from the export process, or at least from the placing of the final product in the market. It is quite clear that there is a problem of control over the economic process, and in particular over certain cycles, which is a strategic node for potential endogenous development.

There is a further problem with the designation of origin, as we had predicted. The name Chilean mussel (it used to be called "chorito") follows an export policy which transcends endogenous territorial identities and interests. In fact the name "Chilean mussel" is a response to the opportunity which has opened up in the Spanish market. It has been assumed almost as a matter of public policy in order to attract private investors. In theory, but only in theory, this is supposed to have a trickle-down benefit 
for the local populations (Gardner and Lewis, 1996). In this context the specific origin of the products is of secondary importance. Nevertheless there have been - timid, it must be said - proposals through the interventions cited above (Fondef-Huam) to give real additional value to seed from the Reloncaví Estuary. This is an effect of the problem of producing only the base material for the final product. As we will see now, neither this nor any other possible strategies have been formulated by local actors. This is an important point when a link is created between collective action and appropriation (or profitability) of the symbolic values involved in seed as a product.

A second consideration is the fact that use of the designation of origin is limited to artisanal fish farmers by law. This arises because, as established in the General Law on Fishing and Aquaculture, the exploitation of natural banks of mytilids is the exclusive right of artisanal fishermen. The problem is that seed capture occurs on natural mussel banks, and only a few members are registered as artisanal fishermen with the Fisheries Department.

The predominant base organisations for production in the coastal communities of the Reloncaví Estuary (small settlements of seashore farmers) are the syndicates of artisanal fishermen. A number of subtleties arise in this situation. In the first place, the communities do not, strictly speaking, exist either as a legal concept or as empirical social structures; but nor do any scattered groupings of true micro-enterprises exist. For this reason the description of the systems seeks to take into account a hybrid economic condition, in which various logics and dynamics (productive and organisational) cross and inter-relate.

Perhaps one of the principal conclusions that can be drawn at this stage is the fact that the eight artisanal fishermen's communities studied in Reloncaví, where mussel seed is captured, present variations of a common model. So we have a diversity which is limited by its own institutional matrix. Of course this includes mussel farming, but is not limited to it, since it embraces the whole local economic system. In practice we find a number of syndicates, which follow three different models based on different economic-organisational rationales - polarised between collectivist and individualist orientations. In order to coordinate some aspects, particularly state subsidies and programmes, a federation has been formed of the syndicates on the Estuary, which has also acted as a commercial platform in specific cases. The production and commercialisation model followed differs from one syndicate to another, and these differences must be established.

We identified three basic variations of a common model for seed capture, and three more for seed commercialisation or delivery. The three variations in capture are: 1) capture with individual lines in collective waters; 2) capture with lines organised by groups in collective waters; 3) capture with individual lines in individual waters. In commercialisation the three variations are: 1) sale-delivery by intermediaries; 2) sale-delivery by service providers; 3) direct sale-delivery. At the harvesting level, which comes between these two processes, the models combine direct harvesting by syndicate members and the hiring of temporary labour.

The mussel farmers have recently formed a trade association: Asociación Gremial de Mitilicultores (AGM). The association was created because the "micro-entrepreneur" mussel farmers saw that an organisation based on membership (syndicates and the federation) limited their growth aspirations. The organisation consists of ten local micro-entrepreneurs, who have remained members of their syndicates. Furthermore, the president of AGM is also president of the Federation of artisanal fishermen.

As has been said, in formal, legal terms the cultivation system is regulated by the General Law on Fishing and Aquaculture, which grants sectors of marine space in concession to individuals against presentation of a technical project. In general, since the Law was passed in 1991, the concessions have been applied for by, and granted to, businessmen, especially salmon and mussel farmers. This is directly related to their operational and financial capacity, required to start up a farming system. At the same time the Law established a second administrative mechanism for specific portions of territory, the Areas for the Management and Exploitation of Benthic Resources (AMERB). The AMERB were always intended for syndicates of artisanal fishermen and at first were only for management activities. Today the AMERB also allow management of other species (originally created to avoid the collapse in the production of abalone, Concholepas concholepas), and cultivation of species like mussel, including seed capture. In this framework, as we have stated, the fishermen's organisations in the Estuary have been working in aquaculture activities for slightly over a decade. Their strategy has been to combine the two mechanisms, i.e. to install capture lines in management areas. This avoids the drawn-out process of applying for a concession, while achieving the technical purpose, and explains why the institutional basis of the artisanal system are the syndicates - for capture, harvesting and commercialisation. Nevertheless, today the fishermen hold concessions as individuals, and AMERBs as syndicate members.

In practice the logics of institutional management tend to combine; i.e. the local models - generally invisible to public agencies and private companies (Ostrom, 1990) - end by re-working, with limited and relative success, the norms imposed or transferred from the development assistance organisations. Perhaps therefore we should think in terms of a "hybrid institutions" model (German and Keeler, 2010), including co-management (Berkes, 2009). But still, the question is a delicate one. These are complex processes which in most cases end by undermining local institutional matrices or else generating high impact transformations, particularly in a logic focused on the search to maximise the profitability and administrative efficiency of local productive spaces (Pinkerton and Silver, 2011). To this must be added the 
financial and logistical cost implied in managing an aquaculture concession, particularly considering the irregular and scarce liquidity available in artisanal fishing economies. This limitation can be seen in the following testimony, obtained in an interview with a syndicate leader at the town of Yates, revealing a widespread perception of artisanal fish farmers that collect seeds in the Reloncaví Estuary:

\begin{abstract}
The most serious problem that we have with the concession is purely one of resources, since we as members do not have the resources to get started even with just a few lines, because the investment required is very high. (Interview, April 2010).
\end{abstract}

At the same time, the local re-working of the formulas transferred from the public agencies and the market (AMERB, aquaculture concessions, temporary permits, etc.) express logics of "creative resistance" based precisely on the reformulation of the modernising "designs" using local institutional capacities and cultural experiences (Gudeman and Rivera, 1990; García Canclini, 1990; Comaroff and Comaroff, 2009; Escobar, 2008). The models described above - and all their potential combinations and variations - reflect this, but the interesting point is that they are based on the "native" values of their symbolic and sensory space; in other words this capacity for reformulation and creativity form part of the know-how - and other relational forms - of seashore cultures, a know-how in which all materiality has an ideational significance (Godelier, 1990), and which in practice functions as a symbolicalpractical repertory which allows remodelling of social and economic life. The question that remains concerns the possibility for the local communities who collect seeds to retain that symbolic value, with a material or even pecuniary expression which is beneficial or at least socially profitable, bearing in mind the framework of negotiations, tensions and conflicts inherent to global assemblies situated in a locality.

\section{CONCLUSIONS}

In the Reloncaví Estuary, a combination of environmental conditions and commonly constructed artisanal cultivation practices has generated a local production system based on the cultivation of mussel seed. Under profitability strategies, the pressures exercised by other actors in the value chain (especially marketing and export companies) have resulted in a dynamic of expropriation of the collective symbolic capital by these "finders-keepers". The disempowering of the local community is a result of incomprehension of how value is generated by artisanal fish farmers in a post-industrial economy.

To make progress in correcting these problems, we must re-orient the academic debate on the structures of governance by which common marine resources are managed (Guthman, 2007; Kirby, Hanich and Visser, 2014). The current structure of governance has attempted to in- troduce other production and distribution systems, e.g. scientific and entrepreneurial, which have tried to improve the quality and yield of some aspects of production. However this structure of governance does not help to increase the value retained by the local community, since it is based on the rentier strategies of external actors (Sanz Cañada and Macías Vázquez, 2005). Rather, this structure redistributes income from one set of actors to another in pursuit of a value process which fits better with the logic of modernisation directed by the "finders-keepers". If this were not the case, it seems obvious that - as with Protected Designations of Origin (PDO) - the situation of the artisanal mussel farmers would be considerably improved if public institutions were to promote some kind of fencing of the material resource, combined with a stronger legal capacity of the community to protect the income associated with the dissemination of a common immaterial value. However, for this type of fencing of the material to enable the community to capture more income, it would be necessary, in the case of the Reloncaví Estuary, to first strengthen the symbolic value of local activities by laying more stress on seed production in the preparation of the final product. As long as the final product continues to play the leading role in the market, the extra-territorial actors will have a structural advantage in capturing income.

In a post-industrial economy, the local community could design a value-creation strategy based on modulation of the friction between material and immaterial vectors, enabling it to build a collective symbolic capital sustained on the productive activities actually carried out in the local environment (Macías Vázquez and Alonso González, 2015). In addition to the income associated with geographical differentiation (PDO), other immaterial values could be brought into play, such as tradition, artisanal practices, the environment, the quality of the consumables produced, etc. (St. Martin et al., 2007). This would mean developing a dynamic, changing value strategy, seeking to tune into the wishes and changing preferences of consumers belonging to markets with a tendency towards diversification. In fact, PDO also need to be permanently renewed, adopting hybrid strategies as soon as territorial differentiation no longer represents a sufficient, lasting source of income in the current globalisation process.

To summarise, the case of the Reloncaví Estuary shows us the failure of modernisation policies which are based on converting local producers into modern entrepreneurs. To adopt a successful value strategy in a post-industrial economy, a very different problem must be addressed, namely the difficulties of local communities in managing successfully their own common immaterial values. Faced with the dichotomous logic of neoliberalism, communities must reunite these immaterial values and the associated common material resources, and modulate the friction between them. Progress in this direction requires the public sector not only to sanction adequate fencing of the material, but also to promote the work of cognitive mediators in the field. These mediators could work in various ambits and help to generate a more effective link between the collective 
management of common symbolic capital and the ability of consumers to interpret its meaning. This would guarantee better orientation of the material fencing of immaterial values, and greater control of the earnings by local communities.

\section{NOTES}

1 Since 1995, Chile has been the second largest producer of salmon and trout in captivity after Norway, even after the crisis of 2008 when the industry reached its lowest point in 2010, it achieved a sustained recovery. Net exports in 2009 were 368,992 tonnes and 296,903 tonnes in 2010. Exports recovered to 488,124 tonnes in 2012 and 527,700 tonnes in 2013. (Source: SalmonChile, 2014).

2 At present we are conducting ethnographic research into the economy of the Calbuco archipelago, where we have evidence of the experiences mentioned here. DID-UACH S-2015-46 Project.

3 FONDEF-HUAM Project AQ08I1018

4 Strictly speaking, $100 \%$ of the seeds captured in the Estuary are used in fattening facilities managed by private companies.

5 A department of the Ministry of Economy.

6 This is particularly the case in Chiloé and Calbuco, which have a nationally recognised tradition of artisanal fishing.

\section{REFERENCES}

Agrawal, Arun (2001) "Common property institutions and sustainable governance of resources". World development, 29 (10): 1649-1672. http://dx.doi.org/10.1016/S0305-750X(01) 00063-8.

Alonso González, Pablo (2014) "From a given to a construct: Heritage as a commons". Cultural Studies, 28 (3): 359-390. http:// dx.doi.org/10.1080/09502386.2013.789067.

Araral, Eduardo Jr. (2009) "What explains collective action in the commons? Theory and evidence from the Philippines". World development, 37 (3): 687-697. http://dx.doi.org/10.1016/j. worlddev.2008.08.002.

Bagnara Vivanco, Manuel and Maltrain Donoso, Gastón (2008) "Descripción del sector mitilicultor en la región de Los Lagos, Chile: evolución y proyecciones". FAO Actas de Pesca y Acuicultura, 12. http://www.fao.org/3/a-i0444s/i0444s14.pdf. [consulted 22/December/2015].

Berkes, Fikert (2009) "Evolution of co-management: Role of knowledge generation, bridging organizations, and social learning”. Journal of Enviromental Management, 90: 1692-1702. http://dx.doi.org/10.1016/j.jenvman.2008.12.001.

Boucher, François (2012) "De la AIR A los SIAL: reflexiones, retos y desafíos en América Latina”. Agroalimentaria, 18 (34): 79-90.

Canales, Manuel (2006) "El grupo de discusión y el grupo focal". In Metodologías de la investigación social. Introducción a los oficios, edited by Canales, M. LOM Ediciones, Santiago de Chile: 265-288.

CEPAL (2010) Clusters y políticas de articulación productiva en América Latina. CEPAL, Santiago.

Comaroff, John L. and Comaroff, Jean (2009) Ethnicity, Inc. University of Chicago Press, Chicago. https://www.google.es/url?sa=t\&rct= $\& \mathrm{q}=\&$ esrc $=\mathrm{s} \&$ source $=$ web $\& \mathrm{~cd}=3 \& \mathrm{cad}=\mathrm{rja} \&$ uact $=8 \& \mathrm{ved}=0 \mathrm{ahU}$ KEwjynrfXv- JAhWD1hQKHUC AbEQFgg0MAI\&url=http $\% 3$ $\mathrm{A} \% 2 \mathrm{~F} \% 2 \mathrm{Fw} w \mathrm{w}$.history.ucsb.edu $\% 2$ Farchived $\% 2$ Fcourses $\% 2 \mathrm{Fte}$ mpdownload.php\%3Fattach_id\%3D7018\&usg=AFQjCNGb1MZ wFaj1HIZgJJB09LskdfJs3g [consulted 22/December/2015].

Escobar, Arturo (2008) Territories of difference: place, movements, life, redes. Duke University Press, Durham.

Fernández González, Ángel and Giráldez Rivero, Jesús (2013) Acuicultura y globalización: el caso de la industria del mejillón. Asociación Española de Historia Económica, Madrid.

García Canclini, Néstor (1990) Culturas Híbridas. Estrategias Para Entrar y Salir de la Modernidad. Grijalbo, México D.F.

Gardner, Katy and Lewis, David (1996) Anthropology, development and the post-modern challenge. Pluto Press, London.
Garza-Gil, M. Dolores; Surís-Regueiro, Juan C. and Varela-Lafuente, Manuel M. (2006) "Assessment of economic damages from the Prestige oil spill". Marine Policy, 30 (5): 544-551. http://dx.doi.org/10.1016/j.marpol.2005.07.003.

Gereffi, Gary; Humphrey, John; Kaplinsky, Raphael and Sturgeon, Timothy J. (2001) "Introduction: Globalisation, value chains and development". IDS bulletin, 32 (3): 1-8. http://dx.doi. org/10.1111/j.1759-5436.2001.mp32003001.x.

German, L. and Keeler, A. (2009) "'Hybrid institutions': Applications of common property theory beyond discrete tenure regimes". International Journal of the Commons, 4 (1): 571-596. http://doi.org/10.18352/ijc.108.

Godelier, Maurice (1990) Lo Ideal y lo Material. Taurus, Madrid.

Gudeman, Stephen and Rivera, Alberto (1990) Conversations in Colombia: The Domestic Economy in Life and Text. Cambridge University Press, Cambridge.

Guthman, J. (2007) "The Polanyian way? Voluntary food labels as neoliberal governance". Antipode, 39(3): 456-478. http://doi. org $/ 10.1111 / \mathrm{j} .1467-8330.2007 .00535 . x$.

Harvey, David (2005) A brief history of neoliberalism. Oxford University Press, Oxford.

Harvey, David (2012) Rebel cities: from the right to the city to the urban revolution. Verso Books, London and New York.

Kirby, D. S.; Visser, C. and Hanich, Q. (2014) "Assessment of ecolabelling schemes for Pacific tuna fisheries". Marine Policy, 43: 132-142. http://dx.doi.org/10.1016/j.marpol.2013.05.004.

Larraín, Jorge (2001) Identidad Chilena. LOM, Santiago.

Lockie, S. (2001) "Food, place and identity: consuming Australia's 'Beef Capital'". Journal of sociology, 37 (3): 239-255. http:// doi.org/10.1177/144078301128756328.

Macías Vázquez, Alfredo and Alonso González, Pablo (2015) “Collective symbolic capital and sustainability: Governing fishing communities in a knowledge economy". Marine Policy, 53: 2126. http://dx.doi.org/10.1016/j.marpol.2014.11.014.

Marazzi, Christian (2008) Capital and language: from the new economy to the war economy. Semiotext(e), Cambridge.

Martinic, Mateo (2005) De la Trapananda al Aysén. Una mirada reflexiva sobre el acontecer de la Región de Aysén desde la Prehistoria hasta nuestros dias. Pehuén, Santiago.

Meinzen-Dick, Ruth S.; Di Gregorio, Monica and McCarthy, Nancy (2004) "Methods for studying collective action in rural development". Agricultural Systems, 82 (3): 197-214.

Montañés, Manuel (2005) "La muestra". In Participación y desarrollo comunitario en medio urbano. Experiencias y reflexiones, edited by Martí, J. et al. IEPALA, Madrid.

Mosimane, A. W.; Breen, C. and Nkhata, B. A. (2012) "Collective identity and resilience in the management of common pool resources". International Journal of the Commons, 6 (2): 344362. http://doi.org/10.18352/ijc.298.

Moulian, Tomás (2002) Chile actual: anatomía de un mito. LOM, Santiago.

Muchnik, José; Sanz Cañada, Javier and Torres Salcido, Gerardo (2008) "Localized Agrifood Systems: state of research and perspectives". Cahiers Agricultures, 17: 513-519. http://doi. org/10.1684/agr.2008.0251.

OCDE Chile (2009) Estudios Territoriales de la OCDE. Chile. Ministerio del Interior, Gobierno de Chile, Santiago.

Ostrom, Elinor (1990) Governing the commons: The evolution of institutions for collective action. Cambridge University Press, Cambridge.

Pasquinelli, Matteo (2008) Animal spirits: a bestiary of the commons. NAi, New York.

Pérez-Alemán, Paola (2005) "Cluster formation, institutions and learning: the emergence of clusters and development in Chile". Industrial and Corporate Change, 14 (4): 651-677. http://ssrn. com/abstract $=914661$ [consulted 18/October/2015].

Pinkerton, Evelyn and Silver, Jennifer (2011) "Cadastralizing or coordinating the clam commons: Can competing community and government visions of wild and farmed fisheries be reconciled?". Marine Policy, 35 (1): 63-72. http://dx.doi.org/10.1016/ j.marpol.2010.08.002. 
Pratt, Jeff (2007) "Food Values the Local and the Authentic". Critique of Anthropology, 27 (3): 285-300. http://dx.doi. org/10.1177/0308275X07080357.

Ray, Christopher (1998) "Culture, intellectual property and territorial rural development". Sociologia Ruralis, 38 (1): 3-20. http:// dx.doi.org/10.1111/1467-9523.00060.

Rivas, Gonzalo (2012) "La experiencia de CORFO y la transformación productiva de Chile. Evolución, aprendizaje y lecciones de Desarrollo". Serie Políticas Públicas y Transformación Productiva, 3. Corporación Andina de Fomento, Caracas. http:// publicaciones.caf.com/media/17638/caf_libro_corfo_web.pdf [consulted 17/October/2015].

Rullani, Enzo (2004) Economia della conoscenza: creatività e valore nel capitalismo delle reti. Carocci, Roma.

Saavedra, Gonzalo and Macías, Alfredo (2012) "Tradición e innovación en las comunidades de pesca artesanal del sur de Chile: hacia un enfoque reflexivo del desarrollo endógeno". AIBR. Revista de Antropología Iberoamericana, 7 (1): 33-64.

Sanz Cañada, Javier and Macías Vázquez, Alfredo (2005) "Quality certification, institutions and innovation in local agro-food systems: protected designations of origin of olive oil in Spain". Journal of Rural Studies, 21 (4): 475-486. http://dx.doi. org/10.1016/j.jrurstud.2005.10.001.

Servicio Nacional de Pesca y Acuicultura (2013) Anuario estadístico de pesca. Departamento de Pesca Artesanal, Valparaíso.

Siisiainen, M. (2003) "Two concepts of social capital: Bourdieu vs. Putnam". Paper presented at ISTR Fourth International Conference "The Third Sector: For What and for Whom?". Trinity College, Dublin. http://c.ymcdn.com/sites/www.istr.org/re- source/resmgr/working papers dublin/siisiainen.pdf [consulted 18/October/2015].

Skewes, Juan Carlos; Alvarez, Ricardo and Navarro, Magdalena (2012) "Usos consuetudinarios, conflictos actuales y conservación en el borde costero de Chiloé insular". Magallania (Punta Arenas), 40 (1): 109-125. http://dx.doi.org/10.4067/ S0718-22442012000100006.

Steffen, Hans (1910) Viajes de esploracion i estudio en la Patagonia occidental 1892-1902. Universidad de Chile, Santiago.

St. Martin, K.; McCay, B. J.; Murray, G. D. and Johnson, T. R. (2007) "Communities, knowledge and fisheries of the future". International Journal of Global Environmental Issues, 7 (2): 221-239. http://dx.doi.org/10.1504/IJGENVI.2007.013575.

Torres Salcido, Gerardo (2013) "Sistemas agroalimentarios localizados. Innovación y debates desde América Latina". Revista Internacional Interdisciplinar INTERthesis, 10 (2): 68-94. http://dx.doi.org/10.5007/1807-1384.2013v10n2p68.

Urbina, Ximena (2011) "Análisis histórico-cultural del alerce en la Patagonia Septentrional Occidental, Chiloé, Siglos XVI al XIX". Magallania (Chile), 39 (2): 57-73. http://dx.doi.org/10.4067/ S0718-22442011000200005.

Van Laerhoven, F. and Ostrom, E. (2007) "Traditions and Trends in the Study of the Commons". International Journal of the Commons, 1 (1): 3-28. http://doi.org/10.18352/ijc.76.

Vercellone, Carlo (2008) "The new articulation of wages, rent and profit in cognitive capitalism". Paper presented at the conference The Art of Rent. Queen Mary University School of Business and Management, London. https://hal-paris1.archives-ouvertes.fr/ file/index/docid/645055/filename/The_new_articulation_of_ wagesHall1.pdf [consulted 15/October/20̄15]. 